\title{
Genetic Effects of Mutual Thymus Transplantation between Lines on Marek's Disease Resistance and Immunocompetences in Chickens
}

\author{
Fazlollah Afraz, Yoshio Yamamoto, Masahide Nishibori \\ and Ikuo OKADA \\ Faculty of Applied Biological Science, Hiroshima \\ University, Higashihiroshima-shi 724
}

(Received February 19, 1992)

\begin{abstract}
The genetic effects of thymectomy and thymus transplantation on resistance to Marek's disease (MD) and immunocompetences were studied. Chicks from the IgG-H and IgG-L lines, selected for high and low levels of serum immunoglobulin G (IgG), were thymectomized and some of them were mutually transplanted with the thymus from those of the other line. One group of chicks was inoculated with the JM strain of MD virus and another group was examined for immunocompetences. MD incidence, MD mortality, graft-versus-host reaction (GVHR) competence and antibody titers to sheep red blood cells (SRBC) and Brucella abortus were compared among three groups; control, thymectomized and thymus transplanted. The IgG-L line was more resistant to $\mathrm{MD}$ than the IgG-H line. In the thymectomized groups, MD incidence and MD mortality increased in both lines. Mean days at MD incidence and MD death showed a decreasing trend. In the thymus transplanted groups, MD incidence and mortality were decreased in the IgG-H line which received thymus from the resistant $L$ line and increased in the IgG-L line which received susceptible $H$ line's thymus. A reverse trend was also observed in the mean days at MD incidence and MD death. The GVHR competence was little affected by thymectomy or thymus transplantation. Immune responses to SRBC and Brucella abortus were also not affected by thymectomy. However, thymus transplantation caused a significant decrease of $\mathrm{MD}$ resistance in the $\mathrm{IgG}-\mathrm{H}$ line which received thymus from the $\mathrm{IgG}-\mathrm{L}$ line, although almost no effect was observed in the IgG- $\mathrm{L}$ line which received the IgG-H thymus. It was suggested that MD resistance and immune response competence could be transferred by thymus grafting.
\end{abstract}

Anim. Sci. Technol. (Jpn.) 63 (7) : 675-681, 1992

Key words: Marek's disease, thymectomy, thymus transplantation, immunocompetence, genetic disease resistance

The finding that Marek's disease (MD) resistance in chickens was transplantable by thymus transplantation was first described by SHEIH and Sevolan ${ }^{10}$. They examined the effect of transplantation of thymus between MD resistant $\mathrm{JM}-\mathrm{N}$ and susceptible JM-P lines. When thymectomized JM-P line received JM-N thymus, their $\mathrm{MD}$ resistance increased significantly, although the reverse treatment showed no effect on MD resistance. On the contrary, Gallatin and LoNGENECKER ${ }^{2)}$ reported that mortality from MD was significantly increased in resistant line chicks following neonatal transplantation of thymus of susceptible chicken line. Powell et al. ${ }^{8)}$ have also confirmed GaLlatin and LONGENECKER's results. That is to say, the transfer of MD susceptibility by thymus grafting from the susceptible line into 
the resistant line was possible, but not in the reverse procedure. Thus, the effect of thymus transplantation is still a controversial problem.

In the previous study the authors also tested the genetic effects of thymus transplantation on $\mathrm{MD}$ resistance, using the GVHR-H and $\mathrm{L}$ lines ${ }^{5)}$. However, the results were not so conclusive, since the difference in $\mathrm{MD}$ resistance between the two lines was small ${ }^{12}$. Therefore, further experiments were needed to examine the effects of thymus transplantation.

On the other hand, VAN DER ZIJPP et al. ${ }^{12)}$ reported that genetic resistance to $\mathrm{MD}$ was associated with immune response to sheep red blood cells (SRBC). High responders to SRBC were more resistant to $\mathrm{MD}$ than low responders.

The IgG-H and $\mathrm{L}$ lines, developed by selection for high and low immunoglobulin $\mathrm{G}$ ( $\operatorname{lgG}$ ) levels ${ }^{11)}$, are highly different in MD resistance and immune responses ${ }^{6}$. Then, the present study was planned to examine the genetic effects of thymus transplantation on $\mathrm{MD}$ resistance and also on immune responses, using the $\operatorname{IgG}-\mathrm{H}$ and $\mathrm{L}$ lines.

\section{Materials and Methods}

\section{Chickens}

Chickens were obtained from two White Rock lines, IgG-H and IgG-L, which had been established by eight generations of selection for high and low levels of serum IgG at 10 weeks of age ${ }^{11)}$. After that, the lines were maintained by random mating.

Hatched chicks were then wing-banded and used for the experiments. Chicks were kept in batteries during the whole experimental period in an isolated condition.

Surgical procedures

The detailed procedures of thymectomy and thymus grafting have previously described by Afraz et al. ${ }^{\prime \prime}$.

Challenge experiment of Marek's disease virus
The JM strain of MD virus was supplied from Kanonji Institute, Research Foundation for Microbial Diseases of Osaka University. Chicks of each line were divided into three groups; control, thymectomized and thymus transplanted. All chicks were inoculated intramuscularly with $\mathrm{MD}$ virus of a quantity of $3.9 \times 10^{3}$ plaque-forming units at two days of age after finishing the transplantation operation. The chicks were raised together in an isolation room for 68 days, and MD incidence and MD death were checked daily. The day of MD incidence indicates the day that the chick showed characteristic MD symptoms such as paralysis, and the day of MD death shows the day on which the chick fell down with severe paralysis. Autopsies were performed on each dead chick. The experiment was conducted in two replications.

\section{Graft-versus-host reaction}

The graft-versus-host reaction (GVHR) competence was measured by splenomegaly. To avoid immunological immaturity, blood was obtained from chickens older than 11 weeks of age. Lymphocytes separated from blood samples were suspended in a density of $10^{6}$ cells/ $0.1 \mathrm{ml}$ of phosphate buffered saline. A dose of $0.1 \mathrm{~m} l$ of the suspension was injected into the chorioallantoic vein of 14-day embryos, and 5 days later spleen weight was measured. Usually, five hosts from a strain with different genotypes wore used for each donor. The degree of GVHR was expressed as an index called the splenomegaly index (SI). The SI was calculated by dividing the spleen weight of the embryo in milligrams by body weight in grams.

\section{Immune response}

Washed SRBC and Brucella abortus were suspended in the same physiological saline at concentrations of $10 \%$ and $10^{9}$ cells per $\mathrm{ml}$, respectively. Chickens were injected intravenously with $1 \mathrm{~m} l / \mathrm{kg}$ body weight of the antigens at 12 weeks of age. The chickens were bled one and two weeks after injection. Antibody titers to SRBC and Brucella abortus 
were determined by agglutination test.

\section{Statistical analyses}

For total MD incidence and MD mortality, comparisons among groups were conducted by $\chi^{2}$ tests. Other data were analyzed by the analysis of variance.

\section{Results}

Table 1 summarizes the total MD incidence and MD mortality in each treated or nontreated group. In the non-treated control, MD incidence and mortality in the IgG-H line were as high as 17.95 and $7.69 \%$, respectively, although the IgG-L control showed no incidence and no mortality. The line difference of MD incidence was almost significant statistically $(\mathrm{P}<0.1)$.

After thymectomy both MD incidence and MD mortality were increased in both the $\mathrm{H}$ and $\mathrm{L}$ lines, although the difference from the control was significant statistically only for the incidence in the $\mathrm{H}$ line.

In thymus transplantation groups, total MD incidence reduced in the $\mathrm{IgG}-\mathrm{H}$, when they were compared with the thymectomized group. On the contrary, MD incidence increased in the IgG- $L$ line which received $H$ line's thymus, and the difference from the control was significant statistically. $\mathrm{MD}$ mortality in the $\mathrm{IgG}-\mathrm{H}$ line was lower than that in the control, but that in the $\mathrm{L}$ line stayed at the same level as the thymectomized group, although the differences from the control were not significant in either lines.

Mean days at MD incidence and $\mathrm{MD}$ death are shown in Table 2 . The date also confirm the results given in Table 1. In thymus grafted groups, the mean days at $\mathrm{MD}$ incidence and MD death were delayed in the $H$ line which received the L line's thymus, but became earlier in the $L$ line which received the $H$ line's thymus, although the differences were not significant.

The GVHR competence in each troated group is shown in Table 3 . In the non-treated control groups, the SI value of the IgG-H was significantly higher than the $\mathrm{L}$ line. Thymectomy treatment brought about a little increase of GVHR competence in the IgG-L line, but not in the IgG-H line. Thymus transplantation caused almost no effect in either lines.

Table 4 shows antibody titers to SRBC and Brucella abortus in each treated group. In the untreated control groups the $\operatorname{IgG}-\mathrm{H}$ line showed significantly higher immune responses to both antigens than the IgG- $\mathrm{L}$ line. Thymectomy brought about almost no effect on antibody titers in either lines. On the other hand, thymus transplantation reduced significantly antibody titers" in the IgG-H line grafted with the IgG-L thymus, but not in the $L$ line which received the $H$ line's thymus. The effects of

Table 1. Total MD incidence and MD mortality in each experimental group at 68 days of age

\begin{tabular}{cccccccc}
\hline \hline Line & Thymectomy & $\begin{array}{c}\text { Thymus transplanted } \\
\text { from }\end{array}$ & $\begin{array}{c}\text { No. of chicks } \\
\text { tested }\end{array}$ & \multicolumn{2}{c}{ Total MD incidence(\%) } & MD mortality (\%) \\
\hline \multirow{4}{*}{ IgG-H } & - & - & 39 & $(7)$ & $17.95^{\mathrm{a}}$ & $(3)$ & $7.69^{\mathrm{a}}$ \\
& + & - & 29 & $(15)$ & $51.72^{\mathrm{b}}$ & $(5)$ & $17.24^{\mathrm{a}}$ \\
& + & IgG-L & 27 & $(11)$ & $40.74^{\mathrm{b}}$ & $(1)$ & $3.70^{\mathrm{a}}$ \\
\hline & - & - & 11 & $(0)$ & $0.00^{\mathrm{A}}$ & $(0)$ & $0.00^{\mathrm{A}}$ \\
$\mathrm{IgG}-\mathrm{L}$ & + & - & 21 & $(5)$ & $23.61^{\mathrm{AB}}$ & $(1)$ & $4.76^{\mathrm{A}}$ \\
& + & IgG-H & 21 & $(7)$ & $33.33^{\mathrm{B}}$ & $(1)$ & $4.76^{\mathrm{A}}$ \\
\hline
\end{tabular}

$a-b, A^{-B}$ Means with different superscripts within each column for each line are signjficantly different $(P<0.05)$.

( ) Number of birds attacked or died. 
Table 2. Means and standard deviations of age at MD incidence and MD death

\begin{tabular}{|c|c|c|c|c|c|c|}
\hline Line & Thymectomy & $\begin{array}{c}\text { Thymus transplanted } \\
\text { from }\end{array}$ & $\begin{array}{l}\text { No. of } \\
\text { birds }^{11}\end{array}$ & $\begin{array}{l}\text { Mean days at } \\
M D \text { incidence }\end{array}$ & $\begin{array}{l}\text { No. of } \\
\text { birds } 11\end{array}$ & $\begin{array}{l}\text { Mean days at } \\
\text { MD death }\end{array}$ \\
\hline \multirow{3}{*}{$\lg \mathrm{G}-\mathrm{H}$} & - & - & 7 & $57.0019 .27^{\mathrm{a}}$ & 3 & $63.67 \pm 5.88^{a}$ \\
\hline & + & - & 15 & $49.54 \pm 14.95^{\mathrm{a}}$ & 5 & $50.20 \pm 14.31^{\mathrm{a}}$ \\
\hline & + & $\operatorname{IgG}-\mathrm{L}$ & 11 & $57.91 \pm 13.80^{\mathrm{a}}$ & 1 & $58.00 \pm 0.00^{\mathrm{a}}$ \\
\hline \multirow{3}{*}{$\lg \mathrm{G}-\mathrm{L}$} & - & - & 0 & $>68^{A}$ & 0 & $>68^{A}$ \\
\hline & + & - & 5 & $67.40 \pm 1.34^{\mathrm{AB}}$ & 1 & $65.00 \pm 0.00^{A}$ \\
\hline & + & $\operatorname{IgG}-\mathrm{H}$ & 7 & $53.71 \pm 16.37^{\mathrm{B}}$ & 1 & $65.00 \pm 0.00^{A}$ \\
\hline
\end{tabular}

1) Chickens for which the date of MD incidence or death was not recorded were excluded from the data.

${ }^{a-b}, A-B$ Means with different superscripts within each column for each line are significantly different $(\mathrm{P}<0.05)$.

Table 3. Splenomegaly index (SI) of donor lymphocytes in each experimental group

\begin{tabular}{|c|c|c|c|c|}
\hline Line & Thymectomy & $\begin{array}{c}\text { Thymus transplanted } \\
\text { from }\end{array}$ & GVHR & Line difference \\
\hline \multirow{3}{*}{$\operatorname{Ig} G-\mathrm{H}$} & - & - & $\begin{array}{l}7.56 \pm 1.59^{\mathrm{a}} \\
(10)\end{array}$ & $*$ \\
\hline & + & - & $\begin{array}{c}7.74 \pm 2.21^{a} \\
(13)\end{array}$ & \\
\hline & + & $\mathrm{IgG}-\mathrm{L}$ & $\begin{array}{l}7.80 \pm 1.60^{\mathrm{a}} \\
\quad(14)\end{array}$ & \\
\hline \multirow{3}{*}{$\operatorname{IgG}-\mathrm{L}$} & - & - & $\begin{array}{l}5.93 \pm 1.56^{A} \\
(10)\end{array}$ & $*$ \\
\hline & + & - & $\begin{array}{l}6.20 \pm 1.86^{\mathrm{A}} \\
\text { (5) }\end{array}$ & \\
\hline & + & $\operatorname{IgG}-\mathrm{H}$ & $\begin{array}{c}6.48 \pm 1.49^{A} \\
(8)\end{array}$ & \\
\hline
\end{tabular}

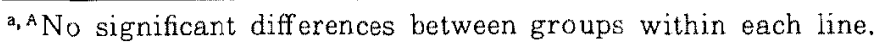

( ) Number of birds used as donor.

* The difference between the $\operatorname{IgG}-\mathrm{H}$ and $\operatorname{IgG}-\mathrm{L}$ lines in the non-treated controls is significant at $\mathrm{P}<0.05$ level.

thymus transplantation were almost the same for both SRBC and Brucella abortus antigens.

\section{Discussion}

OKADA and YAMAMOTO ${ }^{6)}$ reported that the IgG-L line was more resistant to MD than the IgG-H line. The present study confirms their results, although the line difference in the present results was not significant statistically. It seems to be due to the limited number of birds used in the present experiment, especially in the IgG-L line.

After thymectomy, total MD incidence and mortality increased in both $\mathrm{IgG}-\mathrm{H}$ and $\mathrm{L}$ lines. These data support the important role of cellmediated immunity in MD resistance ${ }^{1,3,8-10}$.

Gallatin and Longenecker ${ }^{2)}$ and Powell et $a l^{8}{ }^{8}$ indicated that thymus transplantation from susceptible chickens brought about an increase of the MD susceptibility in resistant chickens. However, the reverse procedure, i.e., grafting the thymi of the resistant line into 
Thymus Transplantation and Marek's Disease Resistance

Table 4. Comparison of antibody responses to SRBC and Brucella abortus between experimental groups

\begin{tabular}{|c|c|c|c|c|c|c|}
\hline \multirow{2}{*}{ Line } & \multirow{2}{*}{ Thymectomy } & \multirow{2}{*}{$\begin{array}{l}\text { Thymus } \\
\text { transplanted } \\
\text { from }\end{array}$} & \multicolumn{2}{|c|}{ SRBC } & \multicolumn{2}{|c|}{ Brucella abortus } \\
\hline & & & $1 \mathrm{wk}$ & $2 \mathrm{wk}$ & $1 \mathrm{wk}$ & $2 w k$ \\
\hline \multirow{4}{*}{$\operatorname{IgG}-\mathrm{H}$} & - & - & $11.40 \pm 1.06^{\mathrm{ab}}$ & $9.13 \pm 1.06^{a * *}$ & $11.73 \pm 0.88^{2 * *}$ & $8.60 \pm 1.06^{a * 0}$ \\
\hline & + & - & $11.92 \pm 1.50^{\mathrm{a}}$ & $9.46 \pm 1.80^{\mathrm{a}}$ & $11.69 \pm 1.18^{\mathrm{a}}$ & $9.15 \pm 1.72^{\mathrm{a}}$ \\
\hline & & & (13) & (13) & (13) & (13) \\
\hline & + & $\mathrm{IgG}-\mathrm{L}$ & $\begin{array}{c}10.73 \pm 1.16^{a} \\
\text { (15) }\end{array}$ & $\begin{array}{l}7.57 \pm 0.76^{b} \\
\text { (14) }\end{array}$ & $\begin{array}{c}10.20 \pm 0.94^{b} \\
\text { (15) }\end{array}$ & $\begin{array}{c}8.07 \pm 0.47^{\circ} \\
(14)\end{array}$ \\
\hline \multirow{3}{*}{$\mathrm{IgG}-\mathrm{L}$} & - & - & $\begin{array}{l}9.10 \pm 1.29^{\wedge} \\
(10)\end{array}$ & $\begin{array}{c}5.00 \pm 0.67^{\mathrm{A}} \\
(10)\end{array}$ & $\begin{array}{l}9.80 \pm 1.39^{A} \\
(10)\end{array}$ & $\begin{array}{l}6.10 \pm 0.74^{\mathrm{A}} \\
\text { (10) }\end{array}$ \\
\hline & + & - & $\begin{array}{l}9.67 \pm 0.82^{A} \\
(6)\end{array}$ & $\begin{array}{l}5.50 \pm 0.55^{A} \\
(6)\end{array}$ & $\begin{array}{c}9.83 \pm 0.75^{A} \\
(6)\end{array}$ & $\begin{array}{c}6.17 \pm 1.83^{A} \\
\text { (6) }\end{array}$ \\
\hline & + & $\lg \mathrm{G}-\mathrm{H}$ & $\begin{array}{l}8.75 \pm 1.28^{4} \\
(8)\end{array}$ & $\begin{array}{c}5.00 \pm 0.75^{A} \\
\text { (8) }\end{array}$ & $\begin{array}{c}9.38 \pm 1.06^{A} \\
(8)\end{array}$ & $\begin{array}{c}6.50 \pm 0.76^{A} \\
\text { (8) }\end{array}$ \\
\hline
\end{tabular}

$a-b$, A Means with different superscripts within each column for each line are significantly different $(\mathrm{P}<0.05)$.

( ) Number of birds tested.

** The differences between the IgG-H and $\operatorname{IgG}-\mathrm{L}$ lines in the non-treated controls are significant at $\mathrm{P}<0.01$ level.

susceptible chickens, did not affect MD resistance of the susceptible recipients. Our previous study was also consistent with their results, although such trend was observed only in MD mortality ${ }^{1)}$. However, SHEin and SEvoIAN ${ }^{103}$ reported different results, namely, that susceptible chicks became more resistant as a result of thymus transplantation from resistant chicks, but no effect in the reverse grafting. In the present study, although the effects of thymus transplantation were observed in both resistant and susceptible lines, $\mathrm{MD}$ incidence of the transplanted group in the $\mathrm{H}$ line was still considerably higher than in the control (Table 1). However, MD mortality of the transplanted group was lower than the control. This difference between MD incidence and mortality seemed to be due to the fact that some period was requested for the working of transplanted thymus and also for recovering from surgical injury. Concerning the effect of thymus transplantation, Gallatin and LONGENECKER $^{2)}$ suggested two possibilities (1) thymus transplants simply provide more susceptible target cells and (2) a transplanted thymus was able to influence the $\mathrm{T}$-cell phenotype in the process when the host's stem cells differentiate into mature $\mathrm{T}$-cells in the thymus gland. The present data support the second hypothesis, since the grafting effect was observed also in the susceptible line which received the resistant line's thymus. If this hypothesis is true, the effect of thymus transplantation should be also observed in GVHR and immune responses. However, the results in GVHR and immune responses did not necessarily support the hypothesis.

Some workers ${ }^{4,7)}$ suggested that the low GVHR competence is attributed to the restraint of proliferation of $\mathrm{T}$ lymphocyte which are target cells of MD virus, and it may lead to MD resistance. Although the line difference in the control groups is in accordance with the hypothesis, the effect of thymus transplantation could not be explained by this.

Effects of thymus transplantation were 


\section{Afraz, Yamamoto, Nishibori and Okada}

also found on immune responses in the $\mathrm{IgG}-\mathrm{H}$ line grafted thymus from the IgG- $\mathrm{L}$ line. Significant decreases in antibody titers were observed in immune responses to both $\mathrm{T}$ celldependent antigen SRBC and $\mathrm{T}$ cell-independent antigen Brucella abortus. The result, therefore, suggests that this decrease is not due to the direct effect of $\mathrm{T}$ cells. On the other hand, the $\mathrm{IgG}-\mathrm{L}$ line which received thymus from the lgG-H line showed no significant change in antibody responses. However, since the number of birds tested in the L line was comparatively small, further experiments might be needed to confirm the results.

\section{Acknowledgments}

The authors wish to thank the Kanonji Institute of the Research Foundation for Microbial Diseases of Osaka University, Kanonji, for the supply of MD virus. This work was supported in part by a Grant-in-Aids for Scientific Research (No.03454099) from the Ministry of Education, Science, and Culture.

\section{References}

1) Afraz, F., Y. Yamamoto and I. Okada, Line difference in effects of thymectomy and thymus transplantation on Marek's disease resistance in chickens. Jpn. Poult. Sci., 28 : 300-305. 1991.

2) Gallatin, W.M. and B.M. Longenecker, Expression of genetic resistance to an oncogenic herpesvirus at the target cell level. Nature, 280 : 587-589. 1979.

3) Gupta, S.K., M.U. Kharole and D.S. KALRA, Role of thymus-dependent immune system in HVT protection against Marek's disease. Avian Dis., 26 : 7-13. 1982.

4) LONGENECKER, B.M., F. PAZDERKA and R.F.
RUTH, Modification by herpesvirus of hereditary GVHR competency. J. Immunogenet., 2 : 59-64. 1975.

5) OKada, I. and H. Mikami, Three generations of selection for high and low donor competences of splenomegaly in chickens. Brit. Poult. Sci., 15 : 1-10. 1974.

6) OKaDA, I. and Y. YAMAмото, Immunocompetences and Marek's disease resistance in three pairs of chicken lines selected for different immunological characters. Poult. Sci, 66 : 769-773. 1987.

7) Pazderka, F., B.M. Longenecker, G.R.J. Law, H.A. Stone and R.F. Ruth, Histocompatibility of chicken populations selected for resistance to Marek's disease. Immunogenetics, 2 : 93-100. 1975.

8) Powell, P.C., L.F. Lee, B.M. Mustill and M. Rennis, The mechanism of genetic resistance to Marek's disease in chickens. Int. J. Cancer, 29 : 169-174. 1982.

9) Sharma, J.M., R.L. Witter and H.G. Purchase, Absence of age-resistance in neonatally thymectomized chickens as evidence for cell-mediated immune surveillance in Marek's disease. Nature, 253: 477-479. 1975.

10) Sheir, H.K. and M. SEvolan, The influence of humoral and cellular immune system on chickens with Marek's disease. J. Chinese Vet. Sci., 4: 3-13. 1978.

11) TAMAKI, Y., Selection for chicken serum IgG levels and disease resistance (in Japanese). Annu. Rep. Nat. Inst. Anim. Ind. (Tsukuba, Jpn.), 20 : 97-104. 1981.

12) VAN DER ZiJPP, A.J., J.J. Blankert, E. Egbers and M.G.J. Tilanus, Advances in genetic disease resistance in poultry. 131138. In: Advances in Animal Breeding. $\mathrm{S}$. Korver, H.A.M. VAN DER STEEN, J.A.M. VAN ARENDOK, H.BAKKER, E.W.BRASCAMP and J. Dommerholt, ed. Pudoc Wageningen. Wageningen, The Netherlands. 1988. 
Thymus Transplantation and Marek's Disease Resistance

\title{
胸腺の系統間相互移植が鶏のマレック病抵抗性 および免疫能力に及ぼす遺伝的効果
}

\author{
Fazlollah Afraz・山本義雄・西堀正英・岡田育穗 \\ 広島大学生物生産学部, 東広島市 724
}

\begin{abstract}
胸腺摘除並びに胸腺移植が鶏のマレック病抵抗性おょび免疫能力に及ぼす息伝的効果について分析し た。免疫グロブリン G（IgG）量について高低 2 方向に選抜した IgG-H および L 系統の七ナを用い て，胸腺摘除並びに胸腺移植を行なった。胸腺の移植は H,L 両系統間で相互交換することにより行な った。胸腺摘除, 胸腺移植および対照群間でマレック病抵抗性, 移植片対宿主反応能並びにヒッジ赤血 球とブルセラ菌に対する兔疫応答能について比較を行なった。マレック病抵抗性は $\mathrm{H}$ 系よりし 系が 大であったが，胸腺摘除群では両系統とも抵抗性の低下が为られた。胸腺移植群では，抵抗性系統であ るL 系の胸腺を移植された $\mathrm{H}$ 系の七ナは抵抗性を回復したが, 感受性系統である $\mathrm{H}$ 系の胸腺を移植 された L系の七ナでは胸腺摘除群よりも更に抵抗性が低下した。移植片対宿主反応能については, 胸 腺摘除も胸腺移植屯ほ上んざ効果を示さなかった。免疫応答では，L 柔の胸腺を移值された H 系にお いてのみ坑体価の有意な減少が観察された。これらの結果から, マレック病抵抗性および免疫応答につ いては, 胸腺移植によって移植された胸腺のもつ遺伝的効果が移植された七ナに移されることが推測さ れた。
\end{abstract}

日畜会報， $63(7) ： 675-681,1992$ 